\title{
Ekspresi IgA dan Rasio CD4+/CD8+ Sel T Mukosa Usus Tikus Setelah Suplementasi Kerang Darah (Anadara granosa)
}

\author{
Netty Ino Ischak, La Ode Aman \\ Fakultas Matematika dan Ilmu Pengetahuan Alam (FMIPA) Universitas Negeri Gorontalo
}

\begin{abstract}
Abstrak
Kerang darah (Anadara granosa) mengandung senyawa glikoprotein yang diperkirakan dapat berperan sebagai zat imunomodulator dengan aktivitas tinggi. Penelitian bertujuan mempelajari potensi kerang darah (Anadara granosa) dalam mekanisme sistem imun tikus (Rattus norvegicus) strain Spraque Dawley. Penelitian dilaksanakan di Laboratorium Kimia Jurusan Kimia FMIPA Universitas Negeri Gorontalo dan Laboratorium Primata Bogor IPB selama periode Maret-Oktober 2015. Peranan itu dijelaskan melalui ekspresi imunoglobulin A (IgA) dan skor histologi rasio CD4+/CD8+ sel T mukosa usus secara imunohistokimia. Metode penelitian adalah eksperimental laboratorik dengan menerapkan randomized post test only control group design terhadap 30 ekor tikus yang dipilih secara simple random sampling. Sampel dibagi dalam lima kelompok: (i) kontrol normal; (ii) dan (iii) adalah sampel malnutrisi yang masing-masing mendapat perlakuan ransum nonprotein sebagai kontrol positif [K.kg(+)] dan ransum standar kasein 20\% sebagai kontrol negatif [K.kg(-)]; serta (4) dan (5) adalah sampel malnutrisi yang mendapat perlakuan ransum protein kasein 10\% yang dikombinasi dengan tepung kerang darah 10\% [P.kg1] dan diberi ransum tepung kerang darah 20\% [P.kg2]. Perlakuan terhadap subjek selama 45 hari. Kondisi malnutrisi (kadar albumin $<2,7 \mathrm{~g} / \mathrm{dL}$ ) diperoleh dengan pemberian ransum nonprotein. Setelah perlakuan, tikus dinekropsi untuk pengambilan jaringan usus. Pemeriksaan IgA dan skor rasio CD4+/CD8+ sel T jaringan mukosa usus (jejunum dan ileum) dengan metode imunohistokimia. Hasil penelitian menunjukkan kerang darah berpotensi meningkatkan kadar IgA, meningkatkan skor histologi CD4+, dan menurunkan skor histologi CD8+ sehingga memengaruhi peningkatan skor rasio $\mathrm{CD} 4+/ \mathrm{CD} 8+$ sel T jejunum dan ileum mukosa usus tikus malnutrisi. Simpulan, terdapat peningkatan jumlah ekspresi IgA pada jejunum maupun ileum mukosa usus kelompok yang diberikan suplementasi kerang darah lebih baik dibanding dengan kelompok tanpa diberi suplementasi.
\end{abstract}

Kata kunci: Ekspresi IgA, kerang darah, rasio CD4+/CD8+, tikus malnutrisi

\section{IgA Expression and Cd4+/Cd8+ T Cell Rasio of Rat Intestine Mucosa After Administation of Anadara granosa}

\begin{abstract}
Anadara granosa contains of glycoprotein that has high activity as immunomodulator. The research objective was to study Anadara granosa's role on immune system mechanism of rats (Rattus norvegicus) Spraque Dawley strain that described by expression of immunoglobulin A (IgA) and histologic score ratio of CD4+/TCD8+ of intestinal mucosa. The study was held in Chemical Laboratory of Chemical Division of FMIPA Universitas Negeri Gorontalo and Laboratory Primata Bogor IPB during March-October 2015. The method was used experimental laboratory with randomized post test only control group design on 30 rats were selected by simple random sampling and divided into five groups: (1) normal controls, (2) and (3) were malnourished subjects to non-protein food as positive control $[\mathrm{K} . \mathrm{kg}(+)]$, and food standard with casein $20 \%$ as negative control [K.kg(-)], (4) and (5) were malnourished subjects thas treated with casein protein diet 10\% combined Anadara granosa flour 10\% [P.kg1], and given Anadara granosa flour 20\% [P.kg2]. The subjects were treated for 45 days. Malnourished condition (albumin $<2.7 \mathrm{~g} / \mathrm{dL}$ ), obtained by non-protein diet. Final step, the samples were operated to get intestinal tissues. IgA examination and CD4+/CD8+ rasio of intestine's mucosal tissues (jejunum and ileum) by immunohistochemically methods. The results showed that Anadara granosa could potentially increased IgA levels and capable to increase histology score of CD4+ and to decrease histology score CD8+. Increasing of CD4+/CD8+ ratio in jejunum and ileum of rats intestinal mucosa with malnourished after be administrated by Anadara granosa flour. In conclusion, IgA expression increased in jejunum and ileum mucosa of supplementation group is better than non-supplementation.
\end{abstract}

Key words: Anadara granosa, CD4+/CD8+ ratio, IgA expression, malnourished rats

Korespondensi: E-mail: nettyischak@gmail.com; laode_aman@ung.ac.id 


\section{Pendahuluan}

Kerang darah (Anadara granosa) mengandung senyawa glikoprotein yang diperkirakan dapat berperan sebagai zat imunomodulator dengan aktivitas tinggi. Komposisi kimia daging kerang darah terdiri atas kadar air 9,47\% (bk), abu 10,62\% (bk), lemak total 2,54\% (bk), serat 2,10\% (bk), karbohidrat 48,01\% (bk), dan protein total $27,26 \%$ (bk). Kandungan mineral terdiri atas $\mathrm{Ca}$ 318,67 ppm, Cu 4,26 ppm, Fe 1720,46 ppm, dan Zn 81,16 ppm. Daging kerang darah komplet mengandung 14 asam amino yang terdiri atas 9 asam amino esensial dan 5 asam amino nonesensial. Kandungan asam amino yang paling tinggi adalah asam glutamat dengan nilai 3,79\%. Asam amino esensial seperti arginin 2,02\%; metionin $0,35 \%$; leusin $1,72 \%$; isoleusin $0,95 \%$; valin 1,07\%; dan histidin 0,22\%. Asam lemak yang tertinggi adalah asam palmitat dengan nilai $45,310 \%$. Asam lemak esensial seperti asam lemak oleat $31,941 \%$ dan asam lemak (omega 3) dengan nilai $3,642 \% .{ }^{1}$

Potensi alternatif kerang darah sebagai bahan pangan yang demikian besar ini menimbulkan berbagai upaya untuk dipergunakan sebagai bahan pangan mengandung sumber protein. Kandungan protein yang tinggi tersebut dapat berkhasiat terhadap peningkatan sistem imun terutama pada anak usia balita yang rentan terhadap defisiensi gizi dan penyakit.

Kondisi malnutrisi diduga dapat memicu potensi infeksi pada bayi. Malnutrisi dapat meningkatkan reactive oxygen species (ROS). Peningkatan ROS ditandai dengan peningkatan nekrosis sel-sel epitel sehingga menyebabkan peningkatan Hsp70. ${ }^{2}$ Peningkatan ROS dapat memicu peningkatan apoptosis sel $\mathrm{T}(\mathrm{CD} 4+)$ dan APC yang dapat berdampak pada semakin menurunnya sel T (CD4+) dan ekspresi IgA. ${ }^{3}$

Imunoglobulin A (IgA) yang dihasilkan oleh sel limfosit merupakan antibodi utama yang berperan dalam sistem imun lokal pada jaringan usus halus. IgA juga mempunyai kemampuan mengaglutinasi agen infeksi dan memfasilitasi proses klirens mikrob melalui gerakan peristaltik dan gerakan mukosilier usus halus. ${ }^{4}$

Keberadaan limfosit T (CD4+) pada mukosa usus sangat memengaruhi produksi dan juga fungsi IgA yang diekspresikan oleh sel plasma. Indikasi bahwa berkurangnya ekspresi IgA sel plasma pada mukosa usus dapat disebabkan oleh berkurangnya aktivasi sel T pada Peyer's patches dan menurunnya kandungan ekspresi limfosit T CD4+ Peyer's patches. ${ }^{5}$

Rasio skor CD4+/CD8+ histologi limfosit merupakan perbandingan antara skor CD4+ dan skor CD8+ histologi limfosit. Peranan skor CD4+ histologi limfosit sangat besar terhadap rasio skor. Pada beberapa penelitian tentang rasio $\mathrm{CD} 4+/ \mathrm{CD} 8+$ sel $\mathrm{T}$ seperti dalam proses penyembuhan CD8+, sel-sel limfosit bersamasama dengan sel limfosit CD4+ turut mengatur dalam proses penyembuhan. CD8+ merupakan downregulator of wound healing, sedangkan CD4+ sebagai upregulator of wound healing. ${ }^{6}$

Peningkatan rasio CD4+/CD8+ sel $\mathrm{T}$ dapat menggambarkan perbaikan proses kerusakan vili-vili usus. ${ }^{6}$ Namun, untuk mengetahui dan menjelaskan bagaimana deskripsi keberadaan IgA dan rasio skor CD4+/CD8+ mukosa usus saluran pencernaan pada keadaan malnutrisi sesudah mendapat suplementasi kerang darah dalam sistem imun saluran pencernaan belum dilaporkan berdasar ilmiah. Informasi ilmiah tentang ekspresi IgA dan rasio $\mathrm{CD} 4+/ \mathrm{CD} 8+$ dapat dikaji melalui penelitian dengan metode imunohistokimia. Metode ini dianggap mampu menggambarkan mekanisme reaksi antibodi itu dengan prinsip imunoenzim.

\section{Metode}

Penelitian ini adalah penelitian eksperimental laboratorik dengan desain the randomized post test only control group design pada 30 ekor tikus (Rattus norvegicus) strain Spraque Dawley sebagai subjek penelitian. Sampel itu dipilih secara simple random sampling, dibagi dalam 5 (lima) kelompok perlakuan sebagai berikut: (i) kelompok kontrol normal $[\mathrm{KN}]$; (ii) dan (iii) adalah kelompok malnutrisi yang masing-masing mendapatkan perlakuan ransum nonprotein sebagai kontrol positif $[\mathrm{K} \cdot \mathrm{kg}(+)]$ dan ransum standar kasein 20\% sebagai kontrol negatif $[\mathrm{K} \cdot \operatorname{kg}(-)]$; serta kelompok (4) dan (5) adalah kelompok malnutrisi yang mendapat perlakuan ransum protein kasein 10\% yang dikombinasi tepung kerang darah 10\% [P.kg1] dan diberi ransum tepung kerang darah 20\% [P.kg2]. Perlakuan subjek penelitian selama 45 hari. Kondisi malnutrisi (kadar albumin $<2,7$ $\mathrm{g} / \mathrm{dL}$ ) diperoleh dengan pemberian ransum yang tidak mengandung protein (nonprotein). Setelah perlakuan, tikus percobaan dinekropsi untuk pengambilan jaringan usus. Pemeriksaan 
imunoglobulin A (IgA) dan skor rasio CD4+/ CD8+ sel T jaringan mukosa usus (jejunum dan ileum) dengan metode imunohistokimia.

Hewan coba yang dipergunakan di dalam penelitian ini adalah tikus (Rattus norvegicus) strain Spraque Dawley umur 3 minggu, bobot 75-105 g, dalam keadaan sehat dan tidak terdapat kelainan anatomis. Penggunaan hewan percobaan telah mendapatkan Sertifikat Laik Etik dari Komite Laik Etik Perguruan Tinggi Universitas Negeri Gorontalo.

Bahan baku utama adalah berupa kerang darah dari spesies Anadara granosa linn yang didapatkan dari pesisir pantai Teluk Tomini, Kabupaten Pohuwato di Provinsi Gorontalo. Pembuatan tepung dari kerang darah (bahan suplementasi) meliputi pencucian, pengukusan, dan pemisahan daging utuh dari cangkangnya, penirisan, pengeringan, kemudian penggilingan. Pengeringan menggunakan sinar matahari untuk mengurangi kadar air. Penggilingan dengan disc mill berukuran 40 mesh dan dihasilkan tepung kerang darah.

Penelitian ini dilaksanakan di Laboratorium Kimia, yaitu Jurusan Kimia FMIPA, Universitas Negeri Gorontalo. Pembuatan preparat histologi dan metode imunohistokimia dilaksanakan di Laboratorium Primata IPB Bogor periode MaretOktober 2015.

Pewarnaan imunohistokimia di atas meliputi beberapa tahap preparasi. Tahap preparasi dimulai dengan preparasi gelas objek, pelapisan (coating) gelas objek dengan poly-L-lysine, penempelan preparat irisan pada gelas objek, dan prosedur pewarnaan imunohistokimia itu sendiri.
Prosedur pewarnaan imunohistokimia itu mencakup tahapan deparafinisasi, rehidrasi, peroksidasi endogen, pencucian dengan destilasi water dan PBS, pemberian antibodi primer (anti-rat IgA polyclonal antibody), pencucian dengan PBS, pemberian antibodi sekunder one step HRP polimer, pencucian, visualisasi dengan DAB (3,3-diaminobenzidine), dicuci atau dimasukkan ke dalam DW/MQ (stopping point), counterstain dengan mempergunakan hematoksilin-DW/MQ, dehidrasi, xilol, serta mounting. Selanjutnya, sediaan histologis siap diamati di bawah mikroskop.

Pemeriksaan imunohistokimia tersebut untuk menentukan skor histologi CD4+, CD8+, dan rasio CD4+/CD8+. Skor histologi dilaksanakan melalui pemeriksaan secara imunohistokimia. Prosedurnya sama seperti ekspresi IgA hanya berbeda antibodi di primernya, yakni antibodi primer $\mathrm{CD} 4+$ dan $\mathrm{CD} 8+$, anti-rat monoclonal dengan pewarnaan metode streptavidin-biotin pada jaringan mukosa usus yang dapat dilihat pada mikroskop cahaya pembesaran 400 kali. Dipilih lapang pandang yang paling banyak sel positifnya dengan pembesaran dan selanjutnya dihitung jumlah sel positif pada lima lapang pandang yang searah jarum jam. Dihitung skor histologi serta dibanding dengan kontrol dan perlakuan.

\section{Hasil Penelitian}

Analisis kandungan imunoglobulin A (IgA) pada jejunum dan ileum mukosa usus halus tikus percobaan itu dilakukan dengan menggunakan teknik imunohistokimia. Hasilnya ditunjukkan

Tabel 1 Deskripsi Kandungan Sekretori Imunogloblin A (sIgA) pada Jejunum dan Ileum Mukosa Usus Halus Tikus Percobaan

\begin{tabular}{|c|c|c|c|}
\hline \multirow{2}{*}{ Perlakuan } & \multicolumn{2}{|c|}{ Ekspresi Imunoglobulin A } & \multirow{2}{*}{ Deskripsi } \\
\hline & Jejunum & Ileum & \\
\hline $\mathrm{KN}$ & ++++ & +++ & $\begin{array}{l}\text { (-) Warna biru menunjukkan bagian tersebut tidak } \\
\text { mengandung sIgA atau warna coklat muda hanya pada } \\
\text { bagian crypt mukosa usus. }\end{array}$ \\
\hline $\mathrm{K} \cdot \operatorname{kg}(+)$ & + & + & $\begin{array}{l}(+) \text { Warna coklat muda hanya pada lapisan epitel dan crypt } \\
\text { atau sebagian besar atau seluruh mukosa usus. }\end{array}$ \\
\hline $\mathrm{K} . \operatorname{kg}(-)$ & ++ & ++ & $\begin{array}{l}(++) \text { Warna coklat tua pada seluruh bagian atau sebagian } \\
\text { besar lapisan epitel dan crypt mukosa usus. }\end{array}$ \\
\hline P.kg1 & ++++ & +++ & $\begin{array}{l}(+++) \text { Warna coklat tua pada seluruh bagian atau sebagian } \\
\text { besar lapisan epitel dan crypt mukosa usus. }\end{array}$ \\
\hline P.kg2 & ++++ & ++++ & $\begin{array}{l}(++++) \text { Warna coklat sangat tua pada seluruh bagian atau } \\
\text { sebagian besar lapisan epitel dan crypt mukosa usus. }\end{array}$ \\
\hline
\end{tabular}


pada Tabel 1.

Hasil pengamatan penelitian ini secara kualitatif menunjukkan bahwa kandungan IgA pada jejunum mukosa usus menurun pada kelompok kontrol positif $\mathrm{K} \cdot \mathrm{kg}(+)$ atau hanya sedikit ditemukan kandungan IgA pada lapisan epitel atau crypt mukosa usus tikus percobaan yang ditandai dengan warna coklat muda pada fotomikrograf.

Perlakuantikus malnutrisiyang mendapatkan suplementasi kerang darah [P.kg2] maupun kombinasinya [kelompok P.kg1] menunjukkan kandungan IgA lebih tinggi daripada kontrol positif. Peningkatan tersebut terlihat dari semakin banyaknya sel yang memberikan reaksi positif terhadap warna coklat pada sebagian besar lapisan sel epitel dan crypt mukosa usus seperti ditunjukkan pada Gambar 1 dan Gambar 2. Gambar 1 memperlihatkan hasil perwarnaan secara imunohistokimia terhadap kandungan sIgA jejunum usus halus yang ditandai dengan warna coklat pada bagian sel epitel dan crypt mukosa usus. Skala $100 \mu \mathrm{m}$ pada tanda panah menunjukkan warna coklat pada lumen usus bagian mukosa. Gambar 2 menunjukkan hasil perwarnaan secara imunohistokimia terhadap kandungan sIgA ileum usus halus yang ditandai dengan warna coklat pada bagian epitel dan crypt mukosa usus. Skala $100 \mu \mathrm{m}$ pada tanda
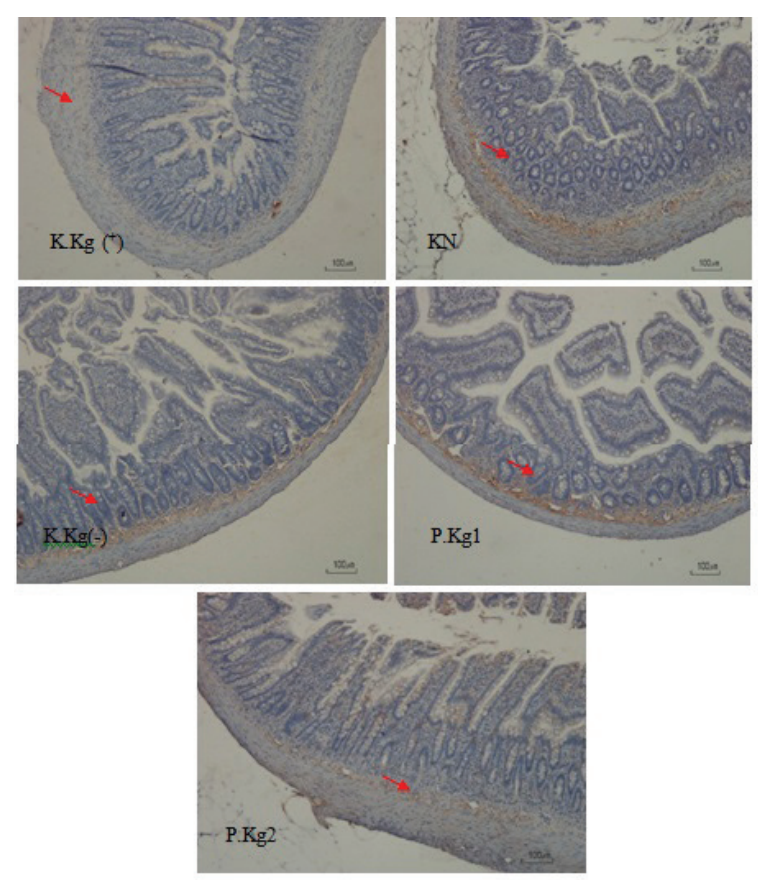

Gambar 1 Fotomikrograf Jejunum Jaringan Mukosa Usus Halus Tikus panah menunjukkan warna coklat pada lumen usus bagian mukosa.

Pengamatan mikroskopi skor histologi CD4+, $\mathrm{CD} 8+$, dan rasio skor histologi $\mathrm{CD} 4+/ \mathrm{CD} 8+$ pada jejunum dan ileum mukosa usus tikus percobaan dengan metode imunohistokimia. Perhitungan skor histologi rasio CD4+/CD8+ berdasarkan atas perbandingan skor histologi CD4+ dan CD8+. Analisis skor histologi rasio CD4+/CD8+ tikus percobaan disajikan pada Gambar 2 yang memperlihatkan bahwa skor histologi rasio $\mathrm{CD} 4+/ \mathrm{CD} 8+$ rata-rata tertinggi terdapat pada perlakuan pemberian tepung kerang darah [P.kg2] sebesar 3,070 sel. Diikuti perlakuan pemberian kombinasi kasein dan tepung kerang darah [P.kg1] sebesar 2,570 sel, perlakuan kontrol normal [KN] sebesar 2,390 sel, kelompok tikus malnutrisi yang diberi kasein [K.kg(-)] sebesar 1,930 sel, dan terendah pada kelompok perlakuan pemberian ransum nonprotein $[\mathrm{K} \cdot \mathrm{kg}(+)]$ sebagai kontrol positif sebesar 1,518 sel.

Jika dibanding dengan kelompok kontrol positif maka pemberian ransum P.kg1 dan P.kg2 mampu dapat meningkatkan skor histologi rasio CD4+/CD8+ tikus percobaan itu. Hasil analisis statistik menunjukkan bahwasanya pemberian kerang darah ke dalam ransum tikus percobaan berpengaruh signifikan $(\mathrm{p}<0,05)$ terhadap skor
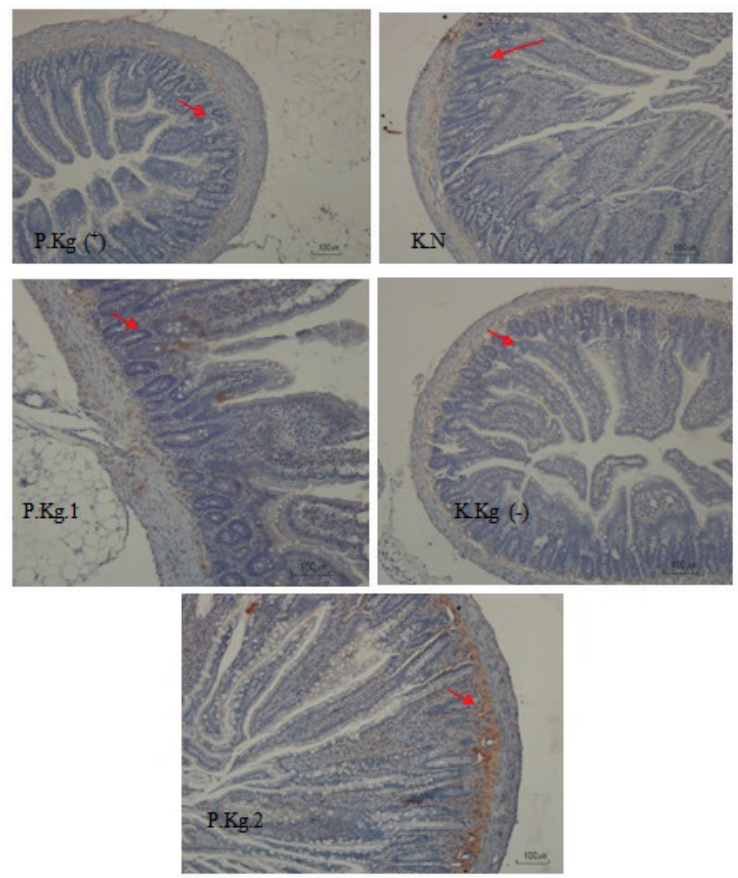

Gambar 2 Fotomikrograf Ileum Jaringan Mukosa Usus Halus Tikus 
histologi rasio $\mathrm{CD} 4+$ /CD8+ tikus malnutrisi. Perubahan peningkatan skor histologi rasio $\mathrm{CD} 4+/ \mathrm{CD} 8+$ itu pada masing-masing perlakuan statistik bermakna, yaitu $\mathrm{p}=0,008$ yang berarti bahwa sel CD8+ pada kelompok perlakuan itu lebih rendah dibanding dengan kontrol positif

Tabel 2 Uji Beda Skor Histologi Antarkelompok Perlakuan CD4+, CD8+, dan Rasio CD4+/CD8+ Tikus Percobaan Setelah Perlakuan

\begin{tabular}{cccc}
\hline \multirow{2}{*}{$\begin{array}{c}\text { Kelompok } \\
\text { Perlakuan }\end{array}$} & \multicolumn{3}{c}{ Rata-rata \pm Simpang Baku } \\
\cline { 2 - 4 } & CD4+ & CD8+ & CD4+/CD8+ \\
\hline KN & $11,169 \pm 0,265$ & $6,169 \pm 0,265$ & $2,269 \pm 0,281$ \\
K.kg(+) & $7,249 \pm 0,254$ & $4,169 \pm 0,265$ & $1,518 \pm 0,105$ \\
K.kg(-) & $12,495 \pm 0,231$ & $4,960 \pm 0,219$ & $2,420 \pm 0,175$ \\
P.kg1 & $12,712 \pm 0,230$ & $4,960 \pm 0,219$ & $2,440 \pm 0,122$ \\
P.kg2 & $12,747 \pm 0,221$ & $6,060 \pm 0,573$ & $2,570 \pm 0,175$ \\
\hline
\end{tabular}

Mann-Whitney UTest ( $\mathrm{p}<0,05)$. Data dinyatakan dalam rata-rata+simpang baku. $\mathrm{CD} 4+\left(\mathrm{p}=0,008^{*}\right) ; \mathrm{CD} 8+\left(\mathrm{p}=0,008^{*}\right) ; \mathrm{CD} 4+/ \mathrm{CD} 8+\left(\mathrm{p}=0,009^{*}\right)$

disajikan pada Tabel 2 dan Gambar 3.

Berdasar uji Mann-Whitney U pada $\alpha=0,05$ memperlihatkan bahwasanya perlakuan P.kg1 tidak memberikan perbedaan yang nyata dengan perlakuan pemberian ransum tepung kerang darah [P.kg2] dan kelompok kontrol negatif $[\mathrm{K} . \mathrm{kg}(-)]$. Perlakuan kontrol normal $[\mathrm{KN}]$ juga tidak memberikan perbedaan yang nyata pada kelompok malnutrisi yang diberikan ransum kasein $\mathrm{K} . \mathrm{kg}(-)$ serta kelompok malnutrisi yang diberi kombinasi kasein dan tepung kerang darah [P.Kg1].

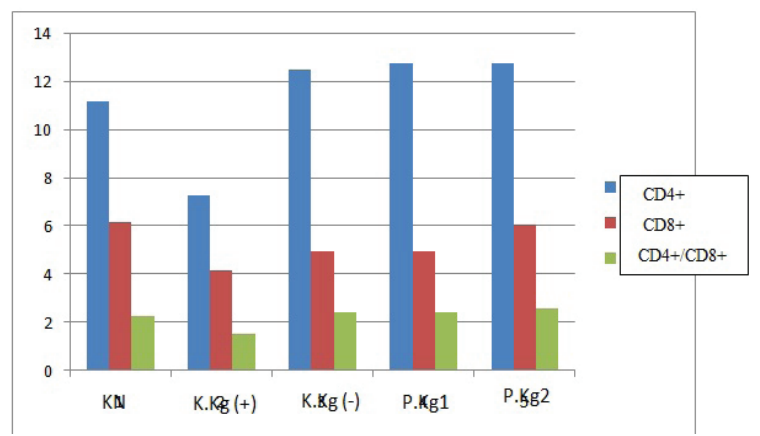

Gambar 3 Diagram Nilai Rata-rata Skor Histologi CD4+, CD8+ dan Rasio CD4+/CD8+ Antarkelompok

Hasil penelitian ini menunjukkan bahwa pemberian tepung kerang darah ke dalam ransum meningkatkan skor histologi rasio CD4+/CD8+ pada jaringan mukosa usus tikus percobaan dalam kondisi malnutrisi. Perbedaan secara maupun kontrol negatif. Rasio skor histologi $\mathrm{CD} 4+/ \mathrm{CD} 8+$ sel $\mathrm{T}$ juga terdapat peningkatan pada kelompok perlakuan dibanding dengan kelompok tanpa diberikan kerang darah dengan $\mathrm{p}=0$,009. Penelitian ini menunjukkan pengaruh signifikan terhadap penurunan skor histologi sel limfosit $\mathrm{CD} 8+$ dan peningkatan rasio skor histologi limfosit CD4+/CD8+.

\section{Pembahasan}

Pertambahan bobot badan berkorelasi dengan konsumsi ransum standar tikus percobaan. Kelompok kontrol positif, yakni tikus malnutrisi yang diberikan ransum nonprotein (restriksi terhadap angka kecukupan gizi) mengalami penurunan bobot badan selama penelitian itu. Namun, kelompok tersebut tetap hidup karena masih mengonsumsi energi yang tersedia dalam ransum walaupun tanpa protein. Penyebab lain yang turut serta memengaruhi bobot badan tikus yang diberikan ransum nonprotein adalah nafsu makan tikus coba yang kurang. Keadaan ini berdampak pada sistem absorbsi usus kurang bagus dan diduga tikus dalam kondisi stres.

Konsumsi ransum tikus sangat dipengaruhi oleh kecukupan kebutuhan energi dari tikus tersebut. Tikus akan berhenti makan apabila kebutuhan energi telah tercukupi. Oleh karena ketersediaan zat-zat gizi itu terutama protein lebih rendah atau tidak ada sama sekali maka tikus akan berusaha untuk memenuhi kebutuhan 
zat gizinya dengan cara mengonsumsi ransum lebih banyak. Pada kelompok tikus malnutrisi yang mendapat perlakuan ransum nonprotein memiliki konsumsi ransum yang lebih rendah. Sebaliknya, pada kelompok tikus malnutrisi setelah diberikan ransum mengandung zat gizi yang lebih baik terutama kandungan protein dan mikromineral yang cukup berasal dari tepung kerang darah dapat meningkatkan bobot badan dan konsumsi ransum hewan percobaan tersebut.

Bila kondisi diet seimbang (protein-energi), kenaikan bobot badan akan terjadi yang sesuai dengan pola pertumbuhan yang seharusnya. Kondisi tersebut akan menjadi lebih buruk bila hewan mendapatkan ransum yang gizinya tidak seimbang. ${ }^{8}$

Selain itu, pada kerang darah didapatkan protein hewani yang mempunyai nilai biologis yang tinggi dibanding dengan protein nabati. Hal ini disebabkan oleh komposisi dan kadar asam amino pada hewan lebih lengkap dan lebih tinggi dibanding dengan komposisi asam amino pada tumbuhan. Peningkatan konsumsi ransum pada kelompok perlakuan tikus malnutrisi dapat juga dipengaruhi oleh kandungan asam amino seperti asam amino glutamat yang terdapat pada kerang darah. Asam amino glutamat merupakan komponen paling penting dalam pembentukan cita rasa pada makanan dari hasil laut seperti kerang darah sehingga makanan terlihat gurih. Kekurangan salah satu jenis asam amino akan menyebabkan keseimbangan nitrogen menjadi negatif. Pembentukan jaringan baru hanya akan terlaksana apabila seluruh asam amino esensial tersedia dalam waktu bersamaan. ${ }^{9}$

Data Tabel 2 menjelaskan bahwa kelompok normal dan juga kelompok yang mendapatkan suplementasi kerang darah tidak berpengaruh nyata terhadap kenaikan jumlah IgA baik pada jejunum maupun ileum mukosa usus. Kadar IgA pada usus tikus yang disuplementasi kerang darah cenderung lebih tinggi daripada kontrol positif. Hal ini disebabkan oleh permeabilitas mikroflora normal saluran cerna pada tikus yang disuplementasi kerang darah mengalami perbaikan atau restorasi lebih baik daripada kontrol positif sehingga respons imun hormonal dalam hal ini IgA dalam tubuh mengalami peningkatan. Hasil ini tidak berbeda jauh dengan hasil penelitian sebelumnya terhadap kadar sekretori imunoglobulin A (sIgA) mukosa usus. ${ }^{10}$
Berdasar hasil pengamatan secara kualitatif pada jejunum mukosa usus menunjukkan ada penurunan kandungan IgA kelompok kontrol positif $\mathrm{K} \cdot \mathrm{kg}(+)$ atau hanya sedikit ditemukan kandungan IgA baik pada lapisan epitel atau crypt mukosa usus tikus percobaan yang ditandai dengan warna coklat muda pada fotomikrograf. Pada perlakuan tikus malnutrisi yang diberi kerang darah [P.kg2] maupun kombinasinya [P.kg1] menunjukkan kandungan IgA lebih tinggi daripada kontrol positif. Peningkatan tersebut terlihat dari semakin banyaknya sel yang memberikan reaksi positif dengan warna coklat pada sebagian besar lapisan epitel dan crypt mukosa usus seperti ditunjukkan pada Gambar 2. Keadaan ini dapat dijelaskan melalui mekanisme sebagai berikut. Peningkatan ROS dapat terjadi pada kondisi malnutrisi yang akan mengakibatkan apoptosis pada antigen precenting cell (APC) yang akan menurunkan ekspresi antigen. Apoptosis yang terjadi pada sel T-CD4+ dan APC akan menyebabkan penurunan ekspresi IgA. Keadaan ini menunjukkan bahwa produksi dan fungsi sIgA yang diskspresikan oleh sel-sel plasma sangat dipengaruhi oleh keberadaan CD4+ limfosit T mukosa usus. Fakta hasil penelitian menunjukkan bahwa pada tikus malnutrisi terjadi penurunan yang bermakna dari kandungan sIgA pada bagian lapisan epitel dan scrypt mukosa serta diikuti oleh penurunan bermakna kandungan IgA pada lamina proporia. Mekanisme yang dapat menjelaskan hal ini adalah apabila timbul respons sel B penghasil IgA mukosa terhadap sel $\mathrm{T}$ dependen antigen maka sel B akan diaktifkan oleh sel $\mathrm{T}$ helper dalam Peyer's patches. Hal ini melalui switch IgA, diferensiasi, dan clonal expansion. Class switching dan malturasi ke dalam sel plasma penghasil IgA diduga terjadi secara lokal di usus. Sel B terutama akan bermigrasi keluar dari Peyer's patches melalui pembuluh limfe ke kelenjar limfe mesenterika, mengalami proses maturasi pada sel plasma, dan pada akhirnya kembali ke lamina proporia melalui darah. Hal ini mengindikasikan bahwa berkurangnya ekspresi sel plasma IgA pada mukosa usus dapat disebabkan oleh berkurangnya aktivasi sel $\mathrm{T}$ pada Peyer's patches dan penurunan kandungan ekspresi CD4+ sel T pada Peyer's patches. Hal yang sama dijelaskan oleh Rey dkk. ${ }^{6}$ bahwa produksi dan fungsi IgA yang diskspresikan oleh sel plasma sangat dipengaruhi oleh keberadaan sel limfosit $\mathrm{T}(\mathrm{CD} 4+)$ mukosa usus. Indikasi 
pengurangan ekspresi sel-sel plasma IgA pada mukosa usus itu dapat disebabkan oleh karena penurunan aktivasi sel T pada Peyer's patches dan penurunan kandungan ekspresi sel T-CD4+ pada Peyer's patches. ${ }^{5,11}$ Bukti ini menjelaskan penurunan kepadatan IgA sel-sel plasma pada lamina proporia ileum.

Pada keadaan malnutrisi sistem imunitas mukosa pada sel $\mathrm{T}$ helper dan produksi antibodi sIgA intestinal sangat penting bagi pertahanan usus tikus percobaan malnutrisi. Sebaliknya, peningkatan sel-sel plasma IgA pada lamina proporia akan mengaktivasi dan mengekspresi sIgA ke permukaan mukosa usus lebih banyak dan akan melindungi permukaan sel terhadap invasi antigen.

Imunoglobulin A (IgA) merupakan protein globulin yang menunjukkan reaksi diakibatkan karena alergen yang masuk ke dalam tubuh. Hal tersebut sesuai dengan penelitian bahwa konsentrasi IgA dalam serum yang menyatakan bahwa IgA disekresi oleh sel B usus memasuki sirkulasi karena terdapat tantangan antigen. Jika antigen itu adalah imunogen (misalnya protein atau asam amino) seperti yang terkandung dalam komponen senyawa kerang darah maka peningkatan kadar IgA pada mukosa usus akan meningkat sejalan dengan perbaikan mikrovili usus yang sebelumnya mengalami malnutrisi. 4,5

Berdasarkan atas hasil penelitian dan analisis statistik dapat disimpulkan bahwa pemberian tepung kerang darah ke dalam ransum tikus percobaan berpengaruh signifikan $(\mathrm{p}<0,05)$ terhadap kenaikan jumlah sel limfosit T (CD4+) tikus malnutrisi. Peningkatan jumlah sel limfosit $\mathrm{T}(\mathrm{CD} 4+)$ pada kelompok tikus yang malnutrisi setelah suplementasi kerang darah maupun kombinasinya dengan kasein menggambarkan bahwa peran nutrisi dalam hal ini kerang darah mempunyai kandungan protein yang adekuat dan mampu untuk meningkatkan jumlah limfosit tubuh. Penurunan kadar limfosit T (CD4+) pada kelompok tikus malnutrisi yang mendapatkan ransum nonprotein dapat disebabkan pula oleh penurunan penyerapan nutrisi dari usus halus akibat gerak laju digesti yang semakin menurun. Diduga pada kondisi malnutrisi, infeksi dapat saja terjadi. Bilamana hal tersebut terjadi maka akan semakin meningkatkan reactive oxygen species (ROS). ROS yang semakin meningkat akan meningkatkan nekrosis epitel. Penelitian lain menyatakan bahwa ROS yang semakin meningkat juga akan semakin meningkatkan apoptosis sel $\mathrm{T}(\mathrm{CD} 4+)$ dan APC yang berdampak pada semakin menurunnya sel $\mathrm{T}(\mathrm{CD} 4+)$ dan ekspresi IgA. ${ }^{10}$

Pada keadaan malnutrisi dapat memicu stres, keadaan ini yang mempunyai dampak terhadap kesehatan dan fisiologis dengan ditunjukkan pada tikus percobaan kontrol positif. Keadaaan ini mempunyai implikasi yang jelas terhadap fungsi sistem imun. Hal ini terbukti dengan skor histologi CD4+ yang menurun sebagai akibat dari peningkatan kortisol dan katekolamin serta penurunan jumlah limfosit secara keseluruhan. ${ }^{12}$

Kerang darah mengandung mineral zink. Peranan zink dalam imunitas sangat penting. Pada keadaan respons imunitas yang bekerja secara spesifik (imun spesifik), defisiensi zink dapat menurunkan jumlah dan fungsi limfosit, penurunan jumlah makrofag, dan penurunan rasio limfosit $\mathrm{T} \mathrm{CD} 4$ (sel helper [Th]); $\mathrm{CD} 8+$ (supresor/sitotoksik (Ts/c). Penurunan jumlah sel limfosit $\mathrm{CD} 8+, \mathrm{CD} 73+$ yang merupakan prekusor sel limfosit $\mathrm{T}$ sitotoksik, penurunan respons antibodi sel limfosit $\mathrm{B}$, dan penurunan sitokin (interleukin-1, IL-2, IL-3, dan interferon ү). Gangguan fungsi yang disebabkan oleh defisiensi zink tersebut akhirnya meningkatkan kerentanan terhadap infeksi, termasuk diare. Pada penelitian ini, hal itu terjadi pada kondisi malnutrisi tikus percobaan sesudah diberikan perlakuan dengan suplementasi kerang darah yang mengandung konsentrasi zink yang cukup adekuat dan ternyata mampu memberikan hasil peningkatan rasio histologi CD4+ dan juga rasio CD4+/CD8+ pada mukosa usus tikus percobaan.

Pada keadaan normal rasio CD4+/CD8+ sebesar 2:1. Caranya adalah membandingkan jumlah CD4+ dengan CD8+ sel limfosit T. Rasio CD4+/CD8+ sel limfosit T dapat dipergunakan untuk dapat mengetahui kerusakan sistem imun tubuh. Pada pelaporan hasil didapatkan angka yang mengindikasikan berapa banyak CD4+ sel limfosit $\mathrm{T}$ yang ada untuk setiap $1 \mathrm{CD} 8+$ sel limfosit T. Limfosit CD4+ (sel T helper) dan $\mathrm{CD} 8+$ (sel $\mathrm{T}$ sitotoksik), pembagian fungsinya mengikuti aturan keseimbangan respons imun. Dalam beberapa kasus sel-sel limfosit T CD4+ mampu memproduksi beberapa sitokin yang mampu untuk memfasilitasi perkembangan dan pematangan dari CD8+. Sel T CD4+ mampu membantu sel $\mathrm{CD} 8+$ dengan menghasilkan CD40 pada APC yang mempunyai efek antigen 
presentasi dan kostimulator. ${ }^{13}$

Skor histologi CD4+ dan CD8+ sel T pada tikus yang mendapatkan suplementasi kerang darah lebih tinggi dibanding dengan tikus tanpa pemberian kerang darah menunjukkan bahwa pemberian kerang darah dapat memaksimalkan peningkatan $\mathrm{CD} 4+$ dan menurunkan $\mathrm{CD} 8+$ sel $\mathrm{T}$ sehingga rasio CD4+/CD8+ sel T mengalami peningkatan pula. Skor CD4+ yang lebih tinggi menunjukkan bahwa kerang darah mengandung komponen senyawa kimia yang lebih berfungsi pada sistem imun humoral dibanding dengan pada sistem imun seluler. Artinya, sistem imun ini lebih banyak bekerja dalam membentuk antibodi daripada menghancurkan jaringan sel yang terinfeksi seperti pada kasus malnutrisi. Temuan ini mendukung penelitian lain yang menyatakan bahwa pemberian kerang darah dapat meningkatkan jumlah limfosit T (CD4+) di dalam serum dan peningkatan $\gamma$-globulin, tetapi kerang darah lebih baik jika dibanding dengan perlakuan lainnya. Dalam hal produksi $\gamma$-globulin pemberian kasein saja sudah cukup untuk meningkatkan $\gamma$-globulin meskipun pada pemberian kerang darah itu dan kombinasinya dengan kasein mampu meningkatkan produksi $\gamma$-globulin jauh lebih tinggi. Fakta ini lebih menguatkan pada kondisi malnutrisi setelah diberi kasein maupun kerang darah, $\gamma$-globulin lebih responsif bila dibanding dengan limfosit $\mathrm{T}$ CD4+. ${ }^{14}$

\section{Simpulan}

Terdapat peningkatan jumlah ekspresi IgA pada jejunum maupun ileum mukosa usus kelompok perlakuan yang diberikan suplementasi kerang darah lebih baik dibanding dengan kelompok tanpa diberi suplementasi. Skor histologi CD4+ meningkat dan CD8+ menurun pada kelompok setelah pemberian suplementasi kerang darah pada kondisi malnutrisi. Terdapat peningkatan rasio skor histologi limfosit CD4+/CD8+ pada kelompok P.kg1 dan P.kg2 dibanding dengan kelompok tanpa kerang darah ( $\mathrm{KN}$ dan $\mathrm{K} \cdot \mathrm{kg}(+))$.

\section{Daftar Pustaka}

1. Abbas AK, Lichtman AH. Basic immunology: functions and disorders of the immune system. Edisi ke-3. Philadelphia: Saunder Elsevier; 2011.
2. Prasetyo HR, Soedarto, Sudarmo SM, Putra ST. Perubahan ekspresi CD4, IgA, PGE2 dan Hsp70 mukosa usus Mus musculus Balb/c kurang energi protein yang diinfeksi cryptosporidium. Surabaya: Airlangga University Press; 2010.

3. Ischak N. Profil asam amino dan asam lemak kerang darah (Anadara granosa) asal Pantai Pohuwato Gorontalo, Palu. Makalah Seminar Nasional Tadulako Palu; 2013.

4. Niers L, Stasse-Wolthuis M, Rombouts FM, Rijkers GT. Nutritional support for infant's immune system. Nutr Rev. 2007 Aug;65(8):347-6o.

5. Mestecky J, Russel MW, Elson CO. Intestinal IgA: novel views on its intestinal in the defence of the largest mucosal surface. Gut. 1999 Jan;44(1):2-5.

6. Rey J, Garin N, Spertini F, Corthesy R. Targeting of secretory IgA to Peyer's patch dendritic and $\mathrm{T}$ cells after transport by intestinal M cells. J Immunol. 2004 Mar; 172(5):3026-33.

7. Dabbs DJ. Diagnostic immunohistochemistry: theranostic and genomic applications. Edisi ke-3. Philadelphia: Saunders Elsevier; 2010.

8. Davis PA, Corless DJ, Aspinal R, Wastell C. Effect of $\mathrm{CD} 4(+)$ and $\mathrm{CD} 8(+)$ cell depletion on wound healing. Br J Surg. 2001 Feb;88(2):298-304.

9. Gibson RS. Principle of nutritional assessment. Edisi ke-2. New York: Oxford University Press; 2005.

10. Ischak NI, Wirjatmadi B, Prijatna Y. Analisis limfosit $\mathrm{T} \mathrm{CD} 4+$, zink serum dan histologi timus pada tikus malnutrisi setelah disuplementasi tepung kerang darah (Anadara granosa). Int J PharmTech Res. 2015;7(2):2014-5.

11. Ou D, Li D, Cao Y, Li X, Yin J, Qiao S, dkk. Dietary supplementation with zinc oxide decreases expression of the stem cell factor in the small intestine of weanling pigs. $J$ Nutr Biochem. 2007 Dec;18(12):820-6.

12. Baron RB. Nutrition. Dalam: Tierney LM, McPhee SJ, Papadakis MA, penyunting. Current medical diagnosis and treatment. Edisi ke-44. New York: Lange Medical Books/McGraw-Hill; 2005. hlm. 1214-42.

13. Cunningham-Rundles S, Moon A, McNeeley DF. Malnutrition and host defense. Dalam: Duggan C, Watkins JB, Walker WA, 
Ekspresi IgA dan Rasio CD4+/CD8+ Sel T Mukosa Usus Tikus Setelah Suplementasi Kerang Darah 137

penyunting. Nutrition in pediatric. Edisi ke4. Hamilton, Ontario, Canada: BC Decker Inc.; 2008. hlm. 261-71.
14. Holmgren J, Czerkinsky C. Mucosal immunity and vaccines. Nat Med. 2005 Apr;11(4 Suppl):S45-53. 